\title{
Production and characterization of antimicrobials from isolate Pantoea agglomerans of Medicago sativa plant rhizosphere soil
}

\author{
Nisha M Nair \\ Department of Microbiology, Karpagam Academy of Higher Education, Coimbatore - \\ 641021 (Tamil Nadu), India \\ R. Kanthasamy \\ PG and Research Centre of Botany, Rani Anna Govt. College for Women, Tirunelveli - \\ 627008 (Tamil Nadu), India

\section{R. Mahesh} \\ PG and Research Centre of Botany, South Travancore Hindu College, Nagercoil - \\ 629002, Kanyakumari District (Tamil Nadu), India

\section{S. Iruthaya Kalai Selvam} \\ PG and Research Centre of Zoology, Jayaraj Annapackiam College for Women \\ (Autonomous), Periyakulam, Theni District - 625601 (Tamil Nadu), India \\ S.Ramalakshmi* \\ Department of Microbiology, Sri Moogambigai Arts and Science College for Women, Pal- \\ acode-Hosur Main Road, Thimmarayanahalli PO, Mallupatti, Dharmapuri Dt. -636805 \\ (Tamil Nadu), India
}

*Corresponding author. E-mail: arulaksh24@gmail.com

\begin{abstract}
Due to rise in drug resistance among pathogens, there is always an urge to look for new drug alternatives. So in this study we aimed to identify the unexplored rhizosphere microflora of alfalfa plant for new antimicrobials. With initial screening for isolates from rhizosphere region for antibacterial activity against selected bacterial pathogens, the isolate AL10 had better activity selected for this study. The isolate mass was cultured and secondary metabolites were extracted using ethyl acetate and subjected to FTIR and GC-MS analysis. Based on functional diversity analysis, the isolate subjected to anti-bacterial activity revealed significant activity against Streptococcus pneumonia, Klebsiella, S. aureus with zone of inhibition in the range of $18-20 \mathrm{~mm}$. Based on GC-MS analysis report ten compounds were identified and 1-Octadecane and 1-nonadecanol were found to be responsible for bio-activity. FT-IR results showed that $\mathrm{N}-\mathrm{H}$ stretching functional group was dominantly present in the extract. Molecular identification of the isolate by 165 rRNA sequencing showed the isolate as Pantoea agglomerans. The results showed that the isolate P.agglomerans, gram negative bacteria had wide antibacterial activity due to 1 Octadecane and 1-nonadecanol. Though Alfalfa plant has been described for various biological activities, this is a first report on rhizosphere region of plant reporting for antibacterial potential microbes.
\end{abstract}

Keywords: Alfalfa plant, Antibacterial activity, Gas chromatography-mass spectrometry, Pantoea agglomerans, Rhizosphere.

\section{INTRODUCTION}

Alfalfa means "father of all foods", is a perennial herbaceous leguminous flowering plant. Medicago sativa, "Queen of Forage plant" can live upto 8 years, fixes high nitrogen than other plants due to its symbiotic association with microbes. The plant possesses deep root system which enables high water holding ability of plants and thereby preventing soil erosion. They are cultivated worldwide, used as fodder for cows for high protein content and fiber (Frame, 2005). M. sativa, a highremedial value plant has been reported to contain

\section{Article Info}

DOI:10.31018/jans.v11i2.2031

Received: March 4, 2019

Revised: April 5, 2019

Accepted: April 11, 2019

\section{How to Cite}

Nair, N. M. et al. (2019). Production and characterization of antimicrobials from isolate Pantoea ag glomerans of Medicago sativa plant rhizosphere soil. Journal of Applied and Natural Science, 11(2): 267- 272 https:// doi.org/10.31018/ jans.v11i2.2031 
dieback diseases (Walterson and Stavrinides, 2015). Pantoea agglomerans are soil dwelling, yellow pigmented (produces carotenoids), plant associated gram negative rod shaped bacteria (Mohammadi et al., 2012).P.agglomerans has been reported for its presence in soil, water, dust, dairy products, fish, insects, humans and animals (Suen et al., 2010; Prakash et al., 2015; Buyukcama et al., 2017). Malboobi et al., (2009) isolated $P$.agglomerans form the rhizosphere region of potato and evaluation studies revealed that phosphate solubilizing activity lead to higher biomass of potato when applied in combination with other isolates.

Researchers have shown that P.agglomerans has protective ability to prevent plant against $P$ seudomonas syringaepv. Syringae (Braun-Kiewnick et al., 2000), also plant growth promoting activities of various crops (Verma et al., 2001; Feng et al., 2006). The reason behind growth promotion in plants can be attributed due to alteration in root architecture thereby increases uptake of water, nutrients and also IAA production (Sergeeva et al., 2007; Kulkarni et al., 2013). The microbe also brings up soil aggregation and moisture control due to production of exopolysaccharides (Amellal et al., 1998). Reports are available proving the efficiency of $P$. agglomerans strains for phosphate solubilisation, therby increasing plant growth and yield of crops (Viruel et al., 2011; Khalimi et al., 2012; Silini-Cherif et al., 2012).

Initially functional diversity studies has been done (unpublished results) on the isolation of microbes from the rhizosphere of alfalfa plant. Out of 32 isolates, this isolate was selected for its amylase, cellulase, protease and phosphate solubilization activities.

Bacillus horikoshii was isolated and molecularly identified from rhizosphere region of Alfalfa plant possessed antibacterial compounds detected by GC-MS (Nisha et al., 2019). This study was aimed at culturing, extraction and identification of bioactive compounds of functionally diverse organism from rhizosphere soil region of Alfalfa plant (Medicago sativa) through GC-MS and FTIR analysis and its antibacterial activity.

\section{MATERIALS AND METHODS}

Sample collection: Soil samples were collected from the rhizosphere region of Alfalfa plant fields during June 2016 from Sulur, Coimbatore, Tamilnadu, India. Studieswere carried out from June 2016 to March 2017.

Isolation and identification of microorganism: One gram of the collected five soil samples were used for serial dilution to isolate microbes by spread plate method. To the nutrient agar plates, $0.1 \mathrm{ml}$ of serially diluted samples $\left(10^{-1}\right.$ to $\left.10^{-7}\right)$ were plated, incubated at $37^{\circ} \mathrm{C}$ for $24-72$ hours. After incubation, bacterial isolates were checked for purity and preserved in glycerol stocks and as nutrient agar slants for further tests.

These colonies were observed for Gram's nature and morphological characters such as size, shape, color, texture, opacity, elevation, margin and mobility. They were further identified using biochemical methods as stated in Bergey's manual for characterization which includes Indole, Methyl Red, Voges Prauskaeur, citrate, urease, TSI slants etc.

Antibacterial activity: The antimicrobial activities of crude extracts of all isolated bacteria were tested against bacterial pathogens ( $P$.aeruginosa, Klebsiella sp, S. aureus, Proteus vulgaricus, S. pneumonia, E. coli, B. cereus) by agar well diffusion method. Muller-Hinton agar (MHA) plates were prepared and the wells were made with sterile cork borer on the agar plates. The overnight grown nutrient broth cultures of all bacterial pathogens were uniformly swabbed on to the surface of MHA plates using sterile cotton swabs. Each $50 \mu \mathrm{l}$ of cell free supernatants were aseptically incorporated into the well and the plates were incubated in an upright position at $37^{\circ} \mathrm{C}$ for $24 \mathrm{~h}$. After incubation, the plates were observed for zone of inhibition.

Production and extraction of the bioactive compounds: For obtaining the large biomass, the active strain of $P$. agglomerans were inoculated into 1 litre of nutrient agar medium and incubated in shaker at $30^{\circ} \mathrm{C}$ at $160 \mathrm{rpm}$ for $36 \mathrm{~h}$. After incubation, the media contents were centrifuged at $10,000 \mathrm{rpm}$ for 10 minutes to obtain the cell free supernatant.

The cell free supernatant extracted with organic solvent - Ethyl acetate and extraction carried out with 3 volume of solvent for $2 \mathrm{~h}$ by using rotary shaker supernatant fractions were flash evaporated at $45^{\circ} \mathrm{C}$ temperature to ensure complete removal of solvent and the extracts were evaporated to dryness. The resulting residues were dissolved in small amount of respective solvents and stored at $-20^{\circ} \mathrm{C}$ until further purified.

Molecular identification and phylogenetic analysis of the bioactive compound

Genomic DNA isolation: DNA isolation from bacterial isolate ( $P$. agglomerans) was performed according to the cold spring harbour lab protocol. Briefly, the isolates were grown in Nutrient Broth (Himedia, India) for $24 \mathrm{~h}$ days at $37^{\circ} \mathrm{C}$. The contents were centrifuged and pellets washed with 1 $\mathrm{ml}$ Tris-EDTA (TE) buffer, resuspended in $500 \mu \mathrm{l}$ TE buffer containing $1 \mathrm{mg} / \mathrm{ml}$ lysozyme, incubated for 2 hrs at $37{ }^{\circ} \mathrm{C}$. About $75 \mu$ of $10 \%$ Sodium Dodecyl Sulfate (SDS) and $125 \mu \mathrm{l}$ of $5 \mathrm{M} \mathrm{NaCl}$ were added to above mixture, centrifuged $(10,000$ rpm for $10 \mathrm{~min}$ at $37^{\circ} \mathrm{C}$ ) and incubated in ice cold ethanol $\left(-70^{\circ} \mathrm{C}\right)$ for $3 \mathrm{~min}$, later in a $65^{\circ} \mathrm{C}$ water bath for $3 \mathrm{~min}$ and on ice for $10 \mathrm{~min}$. About 200 $\mu \mathrm{g} / \mathrm{ml}$ of RNase added, incubated at $37{ }^{\circ} \mathrm{C}$ for 15 
min and further $50 \mu \mathrm{g} / \mathrm{ml}$ of Proteinase $\mathrm{K}$ added and incubated at $37^{\circ} \mathrm{C}$ for $30 \mathrm{~min}$. Following centrifugation at $10,000 \mathrm{rpm}$ for $10 \mathrm{~min}$ at $37^{\circ} \mathrm{C}$, equal volume of phenol/chloroform/isoamyl alcohol $(25: 24: 1)$ added to upper aqueous phase. The upper phase was recovered and mixed with equal volume of chloroform/isoamyl alcohol (24:1). To the aqueous phase, $50 \mu \mathrm{l}$ of $3 \mathrm{M}$ sodium acetate, $300 \mu \mathrm{l}$ of ice-cold isopropyl alcohol was added, incubated at $-20{ }^{\circ} \mathrm{C}$ for $20 \mathrm{~min}$. The DNA precipitated was pelleted, washed twice with $70 \%$ ethanol, blot dried, resuspended in $40 \mu$ of TE buffer and stored at $-20^{\circ} \mathrm{C}$.

Amplification of 16S rRNA gene: 16S rRNA genes were amplified from the extracted genomic DNA using the $8 \mathrm{~F}$ and $1541 \mathrm{R}$ universal eubacterial primers designed to target the conserved regions in the genomic DNA of the isolates and amplify approximately $1.4 \mathrm{~kb}$ length gene. The forward primer 5'-AGAGTTTGATCCTGGCTCAG-3` and reverse primer 5 AAGGAGGTGATCCAGCCGCA -3` were used for amplification (Farris and Olson, 2007).

The PCR mix contained $5 \mu$ of 25 X PCR buffer, 4 $\mu \mathrm{l}$ of $25 \mathrm{mM} \mathrm{MgCl}_{2}, 5 \mu \mathrm{l}$ of $5 \mu \mathrm{M} 518$ Forward primer and $5 \mu \mathrm{l}$ of $5 \mu \mathrm{M} 800$ Revers Primer, $5 \mu \mathrm{l}$ of 1 mMdNTP's, $0.5 \mu \mathrm{l}$ of TaqDNApolymerase (Thermo Scientific, India) and $2 \mu$ of genomic DNA. The reaction volume adjusted and made up to a final volume of $50 \mu \mathrm{l}$ with sterile doubledistilled water and amplified in an automated thermal cycler (Vapo protect Pro S, Eppendorf). The PCR conditions were an initial denaturation stage at $95{ }^{\circ} \mathrm{C}$ for $2 \mathrm{~min}$, followed by 35 cycles of denaturation at $94{ }^{\circ} \mathrm{C}$ for $45 \mathrm{~s}$, annealing at $55^{\circ} \mathrm{C}$ for $60 \mathrm{~s}$, extension at $72{ }^{\circ} \mathrm{C}$ for $60 \mathrm{~s}$ and a final extension step at $72{ }^{\circ} \mathrm{C}$ for $10 \mathrm{~min}$. Negative controls with no DNA template were included in all PCR experiments.

16S rRNA gene sequencing: The Polymerase Chain Reaction (PCR) products purified using Montage PCR Clean up kit (Millipore) and sequenced by Big Dye terminator cycle sequencing kit (Applied BioSystems, USA) and resolved by Applied Biosystems model 3730XL automated DNA sequencing system (Xcelris Laboratories, India).

Phylogenetic analysis: The 16s rRNA sequence

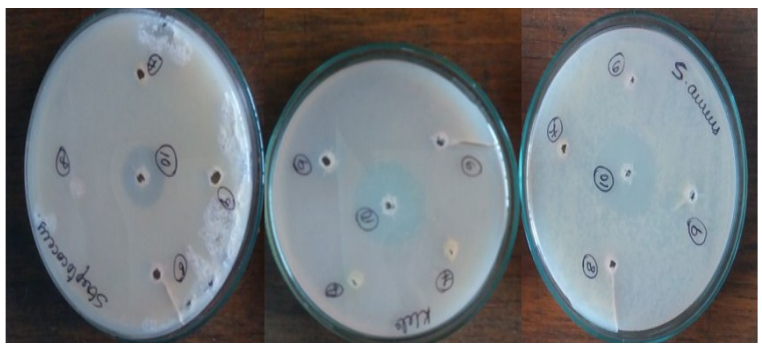

Fig. 1. Showing antibacterial activity of AL10 against Staphylococccus pneumoniae, Klebsiella $s p$ and Streptococcus aureus. blast was done using NCBI blast similarity search tool and for multiple sequence alignment MUSCLE 3.7 program was employed. The resulting aligned sequences were cured using the program Gblocks $0.91 \mathrm{~b}$. This Gblocks eliminates poorly aligned positions and divergent regions (removes alignment noise). PhyML 3.0 aLRT was used for phylogeny analysis and HKY85 as Substitution model.

FTIR analysis: The purified bacterial extract was subjected to FTIR spectroscopic analysis (Perkin Elmer Lambda), equipped with $\mathrm{KBr}$ beam splitter with DTGS (Deuteratedtriglycine sulfate) detector. GC-MS analysis: The Thermo MS DSQ II with DB 35- MS Capillary standard non- polar column and helium as carrier gas $(1 \mathrm{ml} / \mathrm{min})$ was employed for GC-MS analysis. Sample volume of $1 \mu \mathrm{l}$, injector temperature at $260^{\circ} \mathrm{C}$ and oven temperature of $70^{\circ} \mathrm{C}$ (6 min) was employed. Compounds were identified based on mass spectrums using. National Institute Standard and Technology (NIST) database. Through NIST library, name, molecular weight and structure of the components of the test materials were ascertained.

\section{RESULTS AND DISCUSSION}

Antibacterial activity: The rhizosphere region of soil harbor a variety of microbial flora due to the nutrient compounds released from plants roots, thereby playing crucial role in soil function. The antibacterial activity of the crude extract of the isolate $P$.agglomerans studied against 7 clinical pathogens revealed significant zone of inhibition of 18 , 20 and $19 \mathrm{~mm}$ against Streptococcus pneumonia, Klebsiella sp, S. aureus respectively (Fig. 1).

In concordance with our study results, similar results have been obtained for microbial isolate from various rhizosphere region of soil samples possessing significant anti-microbial activity. Jayapradha et al. (2009) reported the wide range of antibacterial activity of Streptomycetes sp. isolated from the rhizosphere soil of medicinal plants at

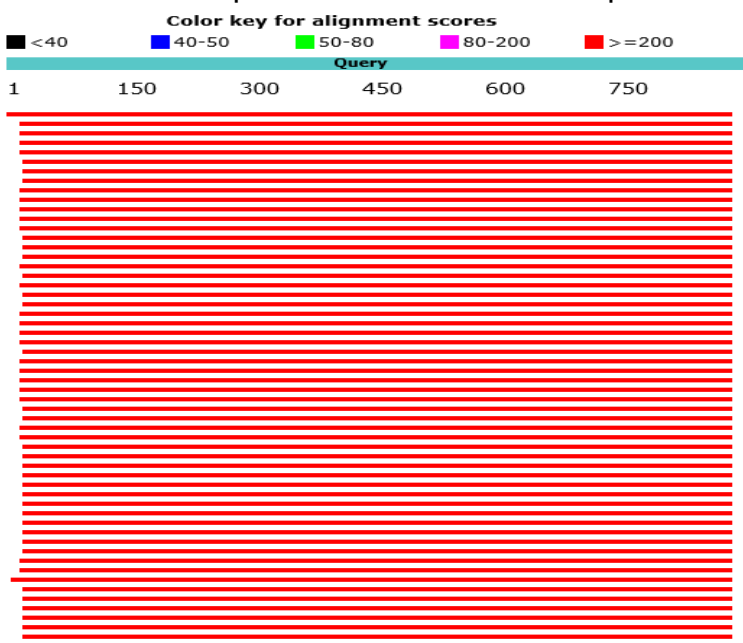

Fig. 2. Showing multiple alignment scores of $P$. agglomerans. 


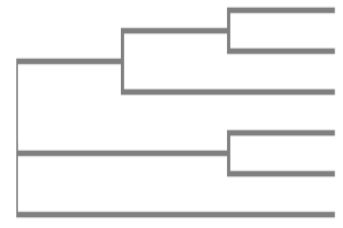

HQ242722.1_Leclercia_adecarboxylata HQ231936.1_Enterobacter_sp. KY938112.1_Enterobacter_asburiae Pantoea_agglomerans MF455204.1_Pantoea_agglomerans JQ781605.1_Enterobacter_sp.

Fig. 3. Phylogenetic tree of $P$. agglomerans based on the 16S rRNA gene sequencing.

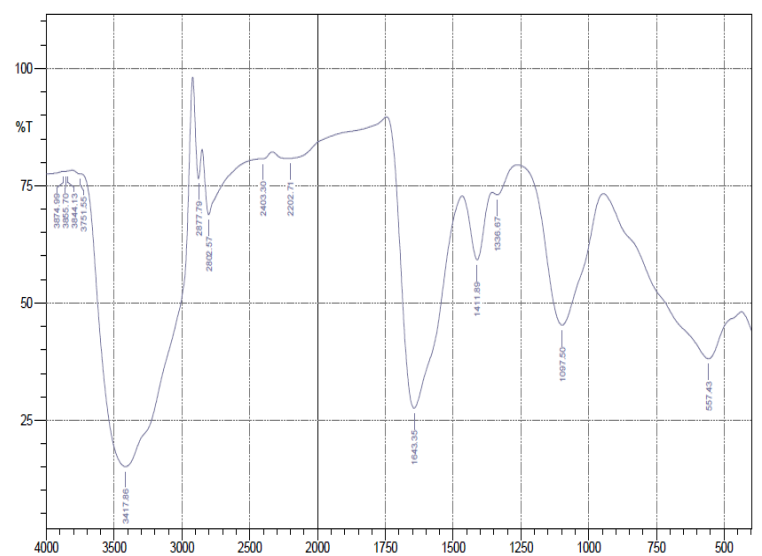

Fig. 4. FTIR spectrum of $P$. agglomerans extract.

Kolli hills of Tamil Nadu. Ryandini et al. (2018) isolated Streptomyces sp.from mangrove rhizosphere mud of Rhizophora mucronata from east Segara Anakan mud and reported significant activity on multipledrug resistant bacteria. Also Rajalakshmi and Mahesh, (2014) reported antimicrobial activity of Aspergillus terrus isolated from rhizosphere region of medicinal plants in and around Kuttralam, Tirunelveli. Upon GC-MS analysis, ten compounds were identified and tetracontane was

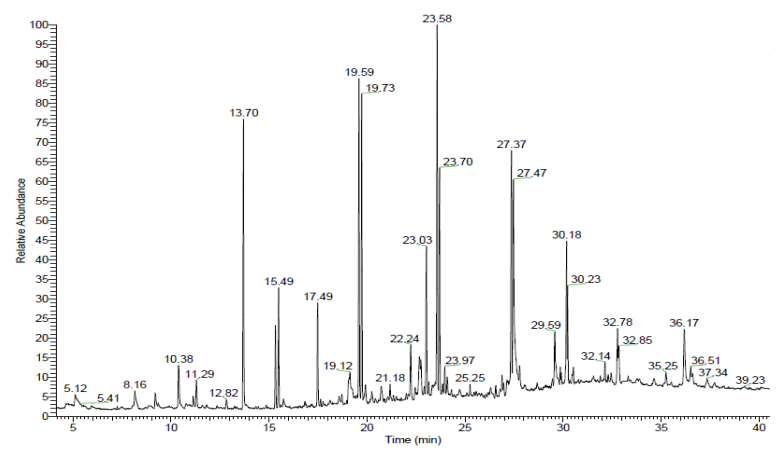

Fig. 5. GCMS spectrum analysis of $P$. agglomerans extract.

reported to be bioactive potential compound.

Molecular characterization of the isolates: The genomic DNA of the isolate isolated and subjected to 16S rRNA gene amplification for the species identification. PCR product of the length 1,400 bp purified and sequenced in Yaazh Xenomics lab, Coimbatore. The 16S rRNA sequences of the isolate subjected to BLAST analysis using mega blast tool of GenBank (http://www.ncbi.nlm.n ih.gov/). Among different species comprising of closet neighbouring strains in NCBI-BLAST analysis used in the phylogenetic analysis. The phylogenetic trees were constructed based on the neighbour joining method and percentage differences in the genetic relationships between the neighbouring strains of the two samples were analyzed.

Results revealed that the $16 \mathrm{~S}$ rRNA partial gene sequence of the isolate showed $100 \%$ similarity with $P$. agglomerans (Fig. 2 and 3 ).

FTIR analysis: Fig 4 depicts the FTIR analysis of the $P$. agglomerans extract showing strong peaks

Table 1. FTIR analysis of P. agglomerans extract.

\begin{tabular}{llllll}
\hline S.N. & Peak & Corr. Intensity & Corr.area & Functional group & Type of vibration \\
\hline 1 & 1658.78 & 16.466 & 15.184 & C=C & stretch \\
2 & 2926.01 & 15.144 & 13.159 & C-H & stretch \\
4 & 715.59 & 11.4652 & 21.998 & =C-H & Bending \\
5 & 1550.77 & 7.518 & 4.53 & C=C & Stretch \\
6 & 1126.43 & 4.671 & 2.412 & C-O & stretch \\
7 & 1409.90 & 3.297 & 1.364 & $-\mathrm{C}-\mathrm{H}$ & bending \\
8 & 3441.01 & 3.379 & 9.616 & O-H & Stretch, H- bonded \\
9 & 2860.43 & 2.75 & 1.018 & C-H & stretch \\
\hline
\end{tabular}

Table 2. Showing GCMS analysis of compounds obtained from $P$. agglomerans extract.

\begin{tabular}{llllll}
\hline S.N. & RT & Name of the compound & $\begin{array}{l}\text { Molecular } \\
\text { Formula }\end{array}$ & MW & $\begin{array}{l}\text { Peak } \\
\text { (\%) }\end{array}$ \\
\hline 1. & 8.18 & Dodecane & $\mathrm{C}_{12} \mathrm{H}_{26}$ & 170 & 0.99 \\
2. & 10.40 & 4-Cyano-2H-1-benzothiopyran & $\mathrm{C}_{10} \mathrm{H}_{7} \mathrm{NS}$ & 173 & 1.77 \\
3. & 13.70 & 2-tert-Butyl-4-isopropyl-5-methylphenol & $\mathrm{C}_{14} \mathrm{H}_{22} \mathrm{O}$ & 206 & 8.60 \\
4. & 15.49 & Hexadecane & $\mathrm{C}_{16} \mathrm{H}_{34}$ & 226 & 5.22 \\
5. & 19.49 & 1-Octadecane & $\mathrm{C}_{18} \mathrm{H}_{36}$ & 252 & 15.15 \\
6. & 23.58 & 1-Nonadecanol & $\mathrm{C}_{19} \mathrm{H}_{40} \mathrm{O}$ & 284 & 15.32 \\
7. & 27.47 & 1-Heneicosyl formate & $\mathrm{C}_{22} \mathrm{H}_{44} \mathrm{O}_{2}$ & 340 & 12.41 \\
8. & 30.18 & 1-Docosanol & $\mathrm{C}_{22} \mathrm{H}_{46} \mathrm{O}$ & 326 & 6.11 \\
9. & 32.80 & 2- Hexadecanol & $\mathrm{C}_{16} \mathrm{H}_{34} \mathrm{O}$ & 242 & 2.94 \\
10. & 36.20 & 9-Octadecenamide & $\mathrm{C}_{18} \mathrm{H}_{35} \mathrm{NO}$ & 281 & 2.89 \\
\hline
\end{tabular}


Table 3. Activity of compounds identified in $P$. agglomerans extract.

\begin{tabular}{|c|c|c|c|c|}
\hline S.N. & RT & Name of the compound & Compound nature & Activity \\
\hline 1. & 8.18 & Dodecane & Alkane hydrocarbon & $\begin{array}{l}\text { Solvent } \\
\text { Antibacterial activity }\end{array}$ \\
\hline 2. & 10.40 & 4-Cyano-2H-1-benzothiopyran & Bicyclic benzene & $\begin{array}{l}\text { Antimalarial } \\
\text { Anti-coagulant }\end{array}$ \\
\hline 3. & 13.70 & $\begin{array}{l}\text { 2-tert-Butyl-4-isopropyl-5- } \\
\text { methylphenol }\end{array}$ & Phenol & Antioxidant \\
\hline 4. & 15.49 & Hexadecane & Alkane hydrocarbon & Detonation of diesel fuel \\
\hline 5. & 19.49 & 1-Octadecane & alkane hydrocarbon & $\begin{array}{l}\text { Antibacterial activity } \\
\text { Antifungal activity }\end{array}$ \\
\hline 6. & 23.58 & 1-Nonadecanol & Fatty alcohol & $\begin{array}{l}\text { Antimicrobial and cytotoxic com- } \\
\text { pound }\end{array}$ \\
\hline 7. & 27.47 & 1-Heneicosyl formate & formic acid & Biocontrol activity \\
\hline 8. & 30.18 & 1-Docosanol & Fatty alcohol & Anti-viral drug \\
\hline 9. & 32.80 & 2- Hexadecanol & Fatty alcohol & Emulsifier \\
\hline 10. & 36.20 & 9-Octadecenamide & Fatty acid & Treatment for mood and sleep \\
\hline
\end{tabular}

at $3417 \mathrm{~cm}^{-1}, 1643.35 \mathrm{~cm}^{-1}, 1097.5 \mathrm{~cm}^{-1}$ and $1658.78 \mathrm{~cm}^{-1}, 2926 \mathrm{~cm}^{-1}, 715 \mathrm{~cm}^{-1}$ respectively. Major group was found to be $\mathrm{N}-\mathrm{H}$ stretching at $3417 \mathrm{~cm}^{-1}$ (Table 1). The FTIR results elucidated an array of functional groups at a frequency ranges indicating the presence of functional groups corresponding to aromatic alkenes, aliphatic amines, compounds with aromatic rings, alkynes, amides, alcohols and phenols in partial fraction of $P$. agglomerans cell free supernatant.

GC-MS analysis: Fig 5 depicts the GC-MS analysis of $P$. agglomerans extract revealing presence of thirty two peaks and ten compounds were characterized and identified by comparison of the mass spectra of the constituents with the NIST library (Table 2 and 3). The retention times (RT) are represented in minutes.

The major constituent of $P$. agglomerans extract was found to be 1-octadecane, an alkane hydrocarbon at retention time 19.49 has highest intensity of 15.15 . Studies have reported the antibacterial and anti-fungal activity of octadecane (Nazemi et al., 2010; Guo et al., 2008). The fatty alcohol 1Nonadecanol was also found highest with intensity of 15.32 and retention time 23.58 minutes, has been reported for antimicrobial and cytotoxic properties (Dalli et al., 2007).

2-tert-Butyl-4-isopropyl-5-methylphenol, a phenolic compound possesses antioxidant activity has been recorded at retention time of $13.7 \mathrm{~min}$ with intensity of 8.6. The formic acid 1-Heneicosyl formate found with intensity of 12.41 and retention time of 27.47 minutes. Fatty alcohol such as 1Docosanol has been found in extract of P.agglomerans with intensity of 6.11 and retention time of 30.80 minutes. 2- Hexadecanol has been recorded at retention time of 32.80 minutes. 9Octadecenamide, a fatty acid was found at retention time of 36.20 minutes.

$B$. horikoshii identified from rhizosphere region of Alfalfa plant possessed antibacterial activity against Klebsiella, Staphylococcus aureus with zone of inhibition in the range of $17-18 \mathrm{~mm}$ and six compounds were detected by GC-MS and 11 Octadecanal responsible for bio-activity (Nisha et al., 2019).

\section{Conclusion}

Based on molecular identification the active isolate of rhizosphere region of Alfaalfa plant identified as $P$. agglomerans and extract identification showed presence of 10 volatile compounds namely Dodecane, 4-Cyano-2H-1-benzothiopyran, 2tert-Butyl-4-isopropyl-5-methylphenol, Hexadecane, 1-Octadecane, 1-Nonadecanol, 1Heneicosyl formate, 1-Docosanol, 2- Hexadecanol and 9-Octadecenamide. And study on the antimicrobial activity showed that activity could be due to presence of 1-Octadecane and 1-nonadecanol. Thus further in vitro and in vivo biological studies are required for anticancer medical applications in various fields. Through this study we were able to isolate new antimicrobials against potent pathogens.

\section{REFERENCES}

1. Amellal, N., Burtin, G., Bartoli, F. andHeulin, T. (1998). Colonization of wheat roots by an exopolysaccharide-producing Pantoeaagglomerans strain and its effect on rhizosphere soil aggregation. Appl Environ Microbiol., 64: 3740-3747.

2. Bialy, Z., Jurzysta, M., Oleszek, W., Piacente, S. and Pizza, C. (1999). Saponins in alfalfa (Medicago sativa L.) root and their structural elucidation. J Agr Food Che., 47: 3185-3192.

3. Bora, K.S. and Anupam Sharma (2011). Phytochemical and pharmacological potential of Medicago sativa: A review. Pharma Biol., 49(2): 211-220. https:// doi.org/10.3109/13880209.2010.504732

4. Braun-Kiewnick, A., Jacobsen, B.J. and Sands, D.C. (2000). Biological Control of Pseudomonas syringaepv. syringae, the causal agent of basal kernel blight of barley, by antagonistic Pantoea agglomerans. Phytopathol., 90: 368-375. doi: 10.1094/ PHYTO.2000.90.4.368.

5. Buyukcama, A.,Tuncer, O., Gür, D., Sancak, B., Ceyhana, M. and Cengiz, A.B. (2017). Clinical and microbiological characteristics of Pantoeaagglomer- 
ansinfection in children. $J$ Infect Public Health., 783: 1-6. https://doi.org/10.1016/j.jiph.2017.07.020

6. Dalli, A.K., Saha, G. and Chakraborty, U. (2007). Characterization of Antimicrobial compounds from a common fern, Pterin biaurita. Indian J Exp Biol., 5: 285-290.

7. El-Khrisy, E.A.M., Abdel Hafez, O.M., Khattab, A.A. and Ahmed, K.M. (1994). Chemical constituents of Medicago sativa L. Bull Nat Res Cent., 19: 117-122.

8. Farris, M. H. \& Olson, J. B. (2007). Detection of Actinobacteria cultivated from environmental samples reveals bias in universal primers. Lett Appl Microbiol., 45: 376-381.

9. Feng, Y., Shen, D. and Song, W. (2006). Rice endophyte Pantoeaagglomerans YS19 promotes host plant growth and affects allocations of host photosynthates. J Appl Microbiol., 100: 938-945. doi:10.1111/ j.1365-2672.2006.02843.x

10.Frame, J. (2005). Medicago sativa L. Grassland Index. A searchable catalogue of grass and forage legumes. FAO, Rome, Italy

11.Guo, L., Wu, J.Z., Han, T., Cao, T., Rahman, K. and Qin, L.P. (2008). Chemical composition, antifungal and antitumor properties of ether extracts of ScapaniaverrucosaHeeg. and its endophytic fungus Chaetomium fusiforme. Molecules, 13(9): 2114-2125. https://dx.doi.org/10.3390\%2Fmolecules13092114

12.Jayapradha, R., Murugesh, S. and Mahesh, N. (2009). Streptomyces sp. SCBT isolated from rhizosphere soil of medicinal plants is antagonistic to pathogenic bacteria. Iran J Biotechnol., 7(2):75-81.

13.Khalimi, K., Suprapta, D.N. and Nitta, Y. (2012). Effect of Pantoeaagglomerans on growth promotion and yield of rice. Agric Sci Res J., 2: 240-249.

14.Krakowska, A., Ska, K.R., Walczak, J., Kowalkowski, T., andBuszewsk, B. (2017). Comparison of Various Extraction Techniques of Medicago sativa: Yield, Antioxidant Activity, and Content of Phytochemical Constituents. J AOAC International., 100(6): 168193. https://doi.org/10.5740/jaoacint.17-0234

15. Kulkarni, G.B., Nayak, A.S., Sajjan, S.S., Oblesha, A. andKaregoudar, T.B. (2013). Indole-3-acetic acid biosynthetic pathway and aromatic amino acid aminotransferase activities in Pantoeadispersa strain GPK. Lett Appl Microbiol. 56: 340-347. https:// doi.org/10.1111/lam.12053

16. Malboobi, M.A., Behbahani, M., Madani, H., Owlia, P., Deljou, A. andYakhchali, B. (2009).Performance evaluation of potent phosphate solubilizing bacteria in potato rhizosphere. World J Microbiol Biotechnol. 25: 1479-1484. http://dx.doi.org/10.1007/s11274-009 $-0038-y$

17.Mohammadi, M., Burbank, L. and Roper, M.C. (2012). Biological role of pigment production for the bacterial phytopathogen Pantoeastewartii subsp. stewartii. Appl Environ Microbiol., 78:6859-6865. DOI: 10.1128/AEM.01574-12

18.Nazemi, M., Khoshkhoo, Z., Motalebi, A. and Karim, H. (2010). Identification non polar component and antibacterial activities of lophonlae vistylus from Persian Gulf. Int J Environ Sci Dev., 6(2): 92- 197.

19.Nisha M Nair, Kanthasamy, R, Mahesh R, Iruthaya Kalai Selvam S and Ramalakshmi S (2019). Identification of Antibacterial Compound from Bacillus horikoshii, isolated from rhizosphere region of Alfalfa plant. J App Sci., 19(2): 140-147. DOI: 10.3923/ jas.2019.140.147.

20.Prakash, O., Nimonkar, Y., Vaishampayan, A., Mishra, M., Kumbhare, S. and Josef, N. (2015).Pantoeaintestinalis sp. nov., isolated from the human gut. Inter. J. Syst. Evol. Microbiol., 65: 33523358. https://dx.doi.org/10.1099/ijsem.0.000419

21.Rajalakshmi, S. and Mahesh, N. (2014). Production and Characterization of Bioactive Metabolites Isolated from Aspergillus terreus in Rhizosphere Soil of Medicinal Plants. Int.J.Curr.Microbiol.App.Sci., 3(6): 784-798.

22.Ryandini, D., Ocky, K.R. and Oedjijono. (2018). Isolate Actinomycetes SA32 Origin of SegaraAnakan Mangrove Rhizosphere and its Capability in Inhibiting Multi-Drugs Resistant Bacteria Growth. J MicrobBiochem Technol., 10(1): 1-7. DOI: 10.4172/19485948.1000386

23. Sergeeva, E., Hirkala, D.L.M. and Nelson, L.M. (2007). Production of indole-3-acetic acid, aromatic amino acid aminotransferase activities and plant growth promotion by Pantoeaagglomerans rhizosphere isolates. Plant Soil., 297: 1-13. https:// doi.org/10.1007/s11104-007-9314-5

24.Silini-Cherif, H., Silini, A., Ghoul, M. and Yadav, S. (2012). Isolation and characterization of plant growth promoting traits of a rhizobacteria: Pantoeaagglomerans Ima2. Pak J Biol Sci., 15: 267-276. http:// dx.doi.org/10.3923/pjbs.2012.267.276

25.Suen, G., Scott, J.J., Aylward, F.O., Adams, S.M., Tringe, S.G., Pinto-Tomás, A.A.(2010). An insect herbivore microbiome with high plant biomassdegrading capacity. PLoS Genet., 6(9): e1001129. https:// doi.org/10.1371/journal.pgen.1001129

26.Verma, S.C., Ladha, J.K. and Tripathi, A.K. (2001). Evaluation of plant growth promoting and colonization ability of endophytic diazotrophs from deep water rice. J Biotechnol., 91: 127-141. https:// doi.org/10.1016/S0168-1656(01)00333-9

27.Viruel. E., Lucca, M.E. andSineriz, F. (2012). Plant growth promotion traits of phosphobacteria isolated from Puna, Argentina. Arch. Microbiol., 193: 489-496.

28.Walterson, A.M. and Stavrinides, J. (2015).Pantoea: insights into a highly versatile and diverse 915 genus within the Enterobacteriaceae. FEMS Microbiol Rev., 5(39): 968-984. https://doi.org/10.1093/femsre\% 2Ffuv027

29.Zhang, L., Zhang, D. and Feng, K. (2006). Inhibition of refined components of Medicago sativa polysaccharides to the activities of reverse transcriptase of HIV and protease of HIV. Zhongguo Shipin Xuebao, 6: 59-62. 